Григорій Капосльоз, кандидат психологічних наук, старший науковий співробітник, ORCID ID 0000-0001-7369-3977

Юрій Бодрик, кандидат технічних наук, старший науковий співробітник ORCID ID 0000-0001-6798-0638

Олена Мельниченко, ORCID ID 0000-0002-6431-5437 Національний університет оборони України імені Івана Черняховського

\title{
ЗАКОРДОННИЙ ДОСВІД ОРГАНІЗАЦІЇ НАУКОВИХ ДОСЛІДЖЕНЬ В IНTЕРЕСАХ ВИЩОЇ ОСВІТИ
}

У статті представлено аналіз досвіду організаиії наукових досліджень в інтересах вищої освіти (органів управління та університетів) США, Великобританії, Франції, Польщі. Установлено невизначеність підходів щзодо організації наукових досліджень в інтересах вищої освіти, проте виявлено рівні організації наукових досліджень, можливих виконавців ичих досліджень, основні завдання їх проведення в інтересах освіти та заходи щодо організації наукових досліджень у галузі вищої освіти та університетах.

Ключові слова: наукове дослідження; освіта; галузь; вищий навчальний заклад.

Постановка проблеми. У законі України «Про освіту» окремою статтею [ст. 75] визначено суб'єктів наукового забезпечення освіти та їх функції. І хоча в п. 3 статті зазначається, що «...Особливості ... наукового і методичного забезпечення освіти для окремих рівнів освіти можуть визначатися спеціальними законами», на сьогодні в нормативно-правових документах відсутні механізми організації наукового забезпечення (проведення наукових досліджень в інтересах) освіти.

Запровадження Законом України «Про вищу освіту» нових, європейських підходів щодо організації підготовки здобувачів вищої освіти підтверджує прагнення України інтегруватися до європейського простору у сфері освіти, що зі свого боку обумовлює необхідність детального аналізу та врахування досвіду розвинутих країн із питань організації наукових досліджень в інтересах вищої освіти загалом та вищих навчальних закладів зокрема.

Аналіз досліджень і публікацій. Аналізуючи досвід організації вищої освіти й наукових досліджень у системі вищої освіти за кордоном автори публікацій акцентують увагу на важливості зосередження у вищих навчальних закладах наукових шкіл [7], супроводження вивчення навчальних дисциплін шляхом наукового пошуку [5], проведення викладачами наукових досліджень [4] для забезпечення навчального процесу в університетах. 
Проте в наукових джерелах не розкривається структура та зміст організації наукових досліджень в інтересах вищої освіти загалом та вищих навчальних закладів зокрема.

Мета статті - виявити стрижневі моменти в організації наукових досліджень в інтересах вищої освіти найбільш розвинутих країн світу.

Виклад основного матеріалу. За допомогою методів аналізу джерел наукової інформації (наукових публікацій, офіційних сайтів, статистичних даних), ii синтезу й експертної оцінки нами узагальнено дані щодо організації наукового забезпечення органів управління освітою та проведення наукових досліджень в інтересах вищих навчальних закладів у США, Великобританії, Франції, Польщі.

Розгляд досвіду організації наукового забезпечення органів управління освітою розпочнемо 3 країни, де освіта, зокрема вища, вважається однією з кращих у світі - США.

Головним органом, який Міністерство освіти США (U.S. Department of Education) використовує для організації наукового забезпечення своєї діяльності, є Інститут педагогічних наук (Institute of Education Sciences, IПН). ІПН створений у межах реформи освіти у 2002 році законодавчим актом Конгресу США як структурний підрозділ Міністерства освіти [11]. Крім наукових досліджень основні напрями його діяльності зосереджені в галузях статистики й оцінювання освітніх програм. Як зазначено у формулюванні місії ІПН, головним його призначенням $\epsilon$ забезпечення наукового обгрунтування політики США в галузі освіти та доведення результатів цієї роботи до громадськості (педагогів, батьків тих, хто навчається, політиків, дослідників) [11].

Головні завдання ІПН охоплюють широкий спектр питань освіти від молодшого дитячого до зрілого віку включно з охопленням таких особливих груп населення, як тих, хто вивчає англійську мову, та учнів 3 обмеженими можливостями. Ці завдання такі:

1. Інформаційне забезпечення даними, що характеризують якість освіти у США. ІПН збирає й аналізує дані офіційної статистики, включно 3 інформацією щодо освіти та грамотності дорослих, бере участь у міжнародних експертизах, проводить національну оцінку освітнього прогресу.

2. Проведення опитувань та фінансова підтримка науково-дослідних проектів із метою виявлення проблемних питань удосконалення освіти та шляхів їх вирішення. Довгострокові опитування IПН забезпечують репрезентативні дані щодо прогресу учнів за весь час навчання у школі до прийняття на роботу. Статистичні дані на основі поперечного зрізу дають змогу отримати уявлення про стан системи освіти й успішність учнів у певні моменти часу. ІПН фінансує дослідження, що використовують ці та інші дані, щоб отримати більш глибоке розуміння природи й контексту необхідних заходів із поліпшення освіти. 
3. Фінансування проектів із розроблення і ретельного тестування нових підходів до підвищення результатів навчання студентів. ІПН підтримує розроблення практичних рішень у галузі освіти, починаючи від початкових стадій проектування до експериментальних досліджень i ретельного тестування. За підтримки ІПН дослідники вивчають, що є дієвим для покращення навчання, поведінки учнів, навчання викладачів, організації системи навчання.

4. Проведення широкомасштабного оцінювання програм i політики федеральної освіти. Воно стосується складних таких питань державного значення, як вплив альтернативних шляхів на підготовку вчителя, систем оцінки педагогічних та лідерських якостей, ініціатив 3 удосконалення навчальних закладів, програм вибору школи.

5. Надання ресурсів для розширення використання даних і результатів досліджень у процесі прийняття рішень у галузі освіти. ІПН через Інформаційний центр із питань якості освіти проводить незалежні рецензування досліджень, спрямованих на підвищення якості освіти. Через мережу регіональних освітніх лабораторій IПН сприяє оволодінню передовими технологіями освіти та здійснює підтримку прикладних досліджень у цій галузі. Грантова програма довгострокової статистики дає змогу кожному штату більш ефективно відстежувати результати навчання i надавати корисну та своєчасну інформацію для осіб, які приймають рішення.

6. Підтримка розвитку статистики й досліджень за допомогою спеціалізованої підготовки та розробки відповідних методів і статистичних показників. ІПН фінансує програми вищої освіти, включно 3 докторськими програмами, а також підготовку фахівців для роботи з базами даних та короткострокові курси підвищення кваліфікації для працюючих статистиків і дослідників. Емпірична робота ІПН над новими методами й статистичними показниками забезпечує постійне підвищення точності, корисності та економічної ефективності як збору даних у галузі освіти, так і наукових досліджень.

Організаційно ІПН складається 3 керівництва інституту та 4-х центрів. Очолює ІПН директор, який призначається Президентом США за рекомендацією і погодженням Сенату. Він має двох заступників - із питань політики й адміністрування та з наукової роботи.

Центри ІПН містять такі структурні підрозділи:

Національний центр досліджень у сфері освіти (National Center for Education Research): Відділення викладання і навчання (Teaching and Learning Division), Відділення політики та систем освіти (Policy and Systems Division).

Національний центр статистики освіти (National Center for Education Statistics): Відділення дошкільної освіти, міжнародної освіти та наскрізної статистики (Early Childhood, International and Cross-cutting Division), Відділення початкової/середньої освіти й бібліотечної справи (Elementary/Secondary and Library Studies Division), Відділення вищої освіти (Postsecondary Division), Відділення оцінювання (Assessment Division). 
Національний центр оцінки освітніх програм та регіональної допомоги (National Center for Education Evaluation and Regional Assistance): Відділення оцінки освітніх програм (Evaluation Division), Відділення застосування знань (Knowledge Utilization Division).

Національний центр досліджень у сфері спеціальної освіти (National Center for Special Education Research).

Аналізуючи завдання та структурну організацію IПН, а також дворічні звіти про його діяльність [12], видно, що наукові дослідження інститут безпосередньо не проводить, а лише здійснює фінансову підтримку науководослідних проектів, укладаючи контракти з іншими науковими установами, організаціями, закладами вищої освіти країни та надаючи гранти.

Напрями досліджень, що фінансуються ІПН, містять [16]:

- пізнання й навчання учнів (Cognition and Student Learning);

- програми та політика раннього навчання (Early Learning Programs and Policies);

- лідерство в освіті (Education Leadership);

- освітні технології (Education Technology);

- ефективні вчителі та ефективне навчання (Effective Teachers and Effective Teaching);

- навчання англійській мові (English Learners);

- удосконалення освітніх систем (Improving Education Systems);

- позашкільна освіта й освіта для дорослих (Postsecondary and Adult Education);

- читання для розуміння (Reading for Understanding Research Initiative);

- освіта для науки, технологій, техніки та математики (Science, Technology, Engineering, and Mathematics (STEM) Education);

- соціальний i поведінковий контекст для академічного навчання (Social and Behavioral Context for Academic Learning).

Схожа з ІПН за назвою установа у Франції - Національний інститут педагогічних досліджень (l'Institut national de recherche pédagogique), що існувала до 2010 року, на відміну від американського закладу безпосередньо здійснювала наукові дослідження в галузі освіти. 32011 року правонаступником цього інституту став Французький інститут освіти (L'Institut français de l'Éducation) - організаційно самостійний підрозділ у складі однієї з престижних так званих «великих шкіл» (Grandes Écoles) Франції - Вищої нормальної школи в Ліоні (l'École normale supérieure de Lyon) [14]. Французький інститут освіти (ФІО) є державною установою, що перебуває у сфері управління Міністерства національної освіти (Ministre de l'éducation nationale) і виконує такі основні завдання:

- проведення досліджень різних форм і практики освіти у Франції та за кордоном;

- підтримка розвитку освітніх систем на всіх рівнях;

- надання підтримки в питаннях управління освітою та оцінки освітньої політики у Франції і міжнародних організаціях; 
- надання початкової та продовженої підготовки в галузі освіти у всіх сферах економічного й соціального життя;

- надання доступу до загальнодержавних наукових ресурсів у галузі освіти;

- створення простору для обговорення найважливіших сучасних проблем освіти.

Наукові дослідження ФІО зосереджені на 4-х головних напрямах:

- побудова елементарного й фундаментального навчання 3 дотриманням балансу між загальними і специфічними знаннями та між формальними й неформальними умовами навчання;

- навчання у школі та поза нею (охорона здоров'я, наука, мистецтво, екологія, засоби масової інформації тощо);

- навчання протягом усього життя («цифрова грамотність», орієнтація, оновлення знань, постійне й безперервне навчання, підготовка кадрів, досвід тощо);

- робота викладачів (у класі та поза класом) від початкової школи до університету, засоби й ресурси для забезпечення їх початкового i продовженого навчання та підтримки діяльності.

Для кожного із зазначених напрямів важливими визнаються такі аспекти:

- якість навчання (ефективність);

- вплив та наслідки застосування цифрових технологій для навчальновиховних процесів (нові форми навчання - повсюдне навчання, мобільне навчання, навчання на основі ігор, соціальні мережі тощо);

- фактор колективу у процесі навчання і викладання;

- освітня політика, іï коріння й результати (характер та еволюція суспільного попиту, структура освітньої політики, освітні програми й навчальні плани).

На відміну від вищерозглянутих установ, що виконують доволі широкий спектр завдань, Науково-дослідний інститут освіти Польщі (Instytut Badań Edukacyjnych) зосереджується в основному на проведенні наукових досліджень у галузі освіти. Він діє під наглядом міністра національної освіти і проводить міждисциплінарні дослідження функціонування та ефективності системи освіти в Польщі.

Основні напрями досліджень інституту містять [13]:

- нові навчальні плани та проблеми предметної дидактики;

- вимірювання й аналіз навчальних досягнень студентів;

- психолого-педагогічна база навчальних досягнень;

- відносини між освітньою системою та ринком праці, зокрема моніторинг молоді, яка виходить на ринок праці;

- навчання протягом усього життя й аналіз систем кваліфікації;

- економічні детермінанти освіти, фінансування освіти та інші загальновизнані проблеми економіки освіти; 
- умови праці, робочий час, професійний статус i повноваження викладачів;

- інституційні та правові проблеми системи освіти й освітньої політики.

Завершуючи огляд існуючих підходів до наукового забезпечення органів управління освітою, окремо зазначимо підхід, що використовує Міністерство освіти Великобританії (Department for Education). Цей орган не має у сфері свого управління спеціалізованого підрозділу 3 досліджень питань освіти. Велику частку аналітичної роботи виконують штатні фахівці Міністерства зі статистики, економіки, соціології, дослідження операцій. Для наукового обгрунтування своєї політики Міністерство освіти в основному використовує зовнішні організації, а для невеликих проектів - групу (об’єднання) аналітичних партнерів (фізичних осіб), які мають спеціалізовані знання в певній галузі знань [9].

У 2016 році група аналітичних партнерів нараховувала 160 незалежних учених та дослідників, які залучалися до аналізу даних, огляду літературних джерел, основних досліджень, рецензування, проведення підготовки, експертизи й контролю якості. 32014 року виконано більше 80 проектів на мінітендерній основі, вартість більшості 3 яких не перевищувала 15000 фунтів.

Таким чином, проведений аналіз доводить, що органи управління освітою різних країн широко використовують результати наукових досліджень у галузі освіти у своїй діяльності. Під час організації наукового забезпечення цих органів застосовується як зовнішній науковий потенціал, так і заклади, що знаходяться у сфері їх управління. Ці заклади, крім проведення наукових досліджень або їх фінансування, можуть виконувати інші завдання 3 підтримки діяльності міністерства освіти - інформаційноаналітичне забезпечення (статистика), оцінювання освітніх програм, підготовка викладачів та дослідників тощо.

У результаті аналізу наукових публікацій, деякі 3 них представлено у списку використаних джерел, установлено, що автори не розкривають структуру та зміст організації наукових досліджень в інтересах вищих навчальних закладів, а саме: відсутній аналіз особливостей замовлення наукових досліджень в інтересах ВНЗ, порядку формування творчих колективів, вимог до результатів наукових досліджень, що впроваджуються в освітню діяльність ВНЗ. Проте нами встановлені певні ознаки наявності такої системи, а саме:

1. Наукові дослідження широко застосовуються для організації навчального процесу магістрів та докторів філософії.

Серед багатьох переваг навчання у США О. А. Луценко [4] виокремлює величезну кількість можливостей щодо проведення наукових досліджень студентами, а саме:

- співпраця з роботодавцями та дослідниками в різних областях науки, навчання та дослідження у промисловості; 
- можливість використання найсучаснішого обладнання (технологій), яке (які) користується(ються) великим попитом у сучасному світі та дає змогу набути нових навичок і досвіду;

- застосування гнучких наукових програм, завдяки яким можна обирати час відвідування занять, кількість відвідуваних протягом семестру або кварталу занять, види факультативних занять тощо, а також які повністю відповідають потребам конкретного студента.

У Франції [2], де «навчання дослідженню за допомогою дослідження» оголошується переважним методом учіння у вищій школі, для досягнення більшої ефективності в підготовці кадрів функціонують:

- тематичні центри передового досвіду, єдине місце зустрічі для іноземних дослідників і докторантів;

- центр підтримки молодих дослідників;

- центр координації публікацій учбових і наукових робіт.

Центри наукових досліджень і вищої освіти були створені з метою об'єднання ресурсів університетів, технічних вузів та науково-дослідних організацій для досягнення більшої ефективності й міжнародної прозорості під час проведення наукових досліджень.

Навчальні заклади Польщі також мають право сприяти дослідницькій роботі молодих вчених [1].

Роль наукових досліджень в організації навчального процесу докторів філософії визначає перший Зальцбурзький принцип: «Стрижневою складовою навчання на докторських програм $\epsilon$ поширення знань через проведення оригінальних досліджень». Одночасно визнається, що докторські студії мають більше відповідати потребам ринку робочої сили, який є значно ширшим за академічну сферу, що визначає практичну спрямованість досліджень.

2. Упровадження результатів досліджень у навчальний процес забезпечує його новітній зміст.

O. В. Тарасова [7] наголошує, що 3 таким завданням найкраще справляються навчальні заклади, у яких не лише зосереджені наукові школи 3 різних галузей, що забезпечують широку міждисциплінарну та фундаментальну базу освіти, але й у яких одержані знання постійно підтримуються власними науковими дослідженнями викладачів, аспірантів i студентів старших курсів.

У цьому контексті у провідних американських вузах діє принцип: «Хто не досліджує, той не викладає». За умовами роботи в американських університетах кожен викладач повинен займатися науковими дослідженнями i при цьому, звичайно, упроваджувати досягнення в навчальний процес, пише О. А. Луценко [4].

У статті Л. Півневої [5] зазначається, що наукове дослідження у вузі своїм предметом супроводжує вивчення навчальної дисципліни шляхом наукового пошуку в певній сфері знання. Організація професійної діяльності 
дослідників вимагає нових форм, а саме: науковий пошук, окремий проект, грант тощо.

Американські вчені пропонують розглядати дві моделі залучення викладачів до наукових досліджень: [5]

перша - це рутинна щоденна робота, коли вчений не обмежений ні крайнім строком, ні стандартом доповіді або чим ще;

друга - це окреме дослідження, визначене чітким строком подачі науково-дослідного матеріалу та доповіді. Ця модель пов'язана із залученням до роботи міжнародного гранту або наукового проекту з підготовки докторів філософії.

2. Здійснюються масштабні дослідження проблем розвитку вищих навчальних закладів та викладання дисциплін.

Організація наукових досліджень для забезпечення функціонування й розвитку вищих навчальних закладів здійснюється на основі стратегічних перспективних довгострокових планів, програм, концепцій. Програми охоплюють основні аспекти багатогранної діяльності ВНЗ і містять питання економіко-правових основ державного управління вищою освітою, розвитку університетів як регіональних центрів науки, освіти і культури, методичних підходів до функціонування багаторівневої системи освіти, вироблення раціональних механізмів інноваційної діяльності ВНЗ та створення при них наукових парків. Прикладами таких програмних документів є:

- Стратегічний план Оксфордського університету на 2013-2018 роки (Велика Британія);

- Стратегічний план Единбурзького університету на 2012-2016 роки (Шотландія);

- Програма стратегічного розвитку федеральної державної бюджетної освітньої установи вищої професійної освіти «Санкт-Петербурзький державний електротехнічний університет «ЛЕТІ» імені В. І. Ульянова (Леніна) » (Російська Федерація).

З 1998 р. велика частина університетів Франції сформувала у своїй структурі орган, що керує науковими дослідженнями - Обсерваторію вчення (Observatoires de I'Etudiant) [3].

Найбільш поширеними формами ведення наукових досліджень педагогів $\epsilon$ такі: науково-практичні дослідження, складання письмових звітів про педагогічну діяльність, ведення педагогічного щоденника, який є засобом професійного самоаналізу. Аналітична робота викладача щодо своєї повсякденної педагогічної діяльності, осмислення змін, експериментів та інновацій, які можна реалізовувати в ній сприяє розвитку професійного мислення викладачів, удосконаленню методики викладання та педагогічної діяльності загалом.

Прикладами результатів досліджень проблем викладання є:

- нова форма наставництва - «теленаставництво», що здійснюється за допомогою мережі (американські вчені Дж. Ейсенман та Х. Торнтон); 
- інноваційна колегіальна форма професійного розвитку НПП супервізія (США, Німеччина);

- розроблення та активне використання тренінгів і практичних занять: «Як навчати дорослих», «Застосування методів ефективного викладання» «Читання лекцій», «Планування курсу й підготовка розкладу», «Проведення дискусій у різноманітних формах», «Безконфліктне викладання», «Проблеми студентів», «Вирішення конфліктів з адміністрацією», «Молодий викладач у системі навчання дорослих», «Методи проблемного навчання» тощо.

3. Фінансування наукових досліджень та форми організації роботи виконавців забезпечують підвищення матеріального благополуччя викладачів, зосередження мотивованих студентів та докторантів в yніверситетах. Результат міжнародної конкуренції за кращих учених визначається ресурсами, які університети й інститути різних країн здатні їм (ученим - лідерам) запропонувати. Аналіз публікацій дає змогу говорити про чотири «мотиваційні ресурси наукових досліджень» для зосередження кращих педагогічних працівників та здобувачів вищої освіти в університетах:

- комериіоналізація досліджень, спрямування їх на отримання прибутку [1]. Завдяки виконанню прикладних досліджень та впровадження їх у виробництво професорсько-викладацький склад має можливість підвищити матеріальне благополуччя [7]. Наприклад, керівник відділу впровадження «extension service» проводить велику роботу 3 викладачами, фермерами, сільськогосподарськими підприємствами й фірмами 3 питань упровадження новітніх розробок у виробництво. При цьому у США існує величезна кількість науково-інноваційних фірм, а на впровадження наукових розробок щорічно тільки в галузі сільського господарства виділяється 1 млрд. 400 млн. дол., крім цього викладачі мають часткове підвищення зарплати вже після впровадження наукової розробки у виробництво [7], - наголошує у своїй статті О. А. Луценко;

- утримання докторантів (посад) за рахунок фінансування наукових досліджень, що здійснюють науково-педагогічні працівники університетів. Саме тому більшість викладачів США ретельно відбирають зі студентів майбутніх докторантів [7].

- використання прачі студентів, які мають необхідні навички в галузі сучасних технологій. Як приклад можна привести кафедру лідерства вищої освіти й міжнародної освіти університету Меріленда в Коледж Парк, на якій працювали 4 студентки по 3-1,5 години на день 2-3 дні на тиждень на умовах мінімальної погодинної оплати праці у країні. За завданням Адміністративного директора (зав. кабінетом) вони виконували окремі види робіт для професорсько-викладацького складу кафедри: відносили й приносили книги для професорів з університетської бібліотеки, розташованої неподалік від корпусу, виконували завдання на комп'ютері, здійснювали пошук наукової літератури, ксерокопіювання книг (на кафедрі були потужні принтери, сканери) тощо. Усе це звільняло час професорів для 
інтелектуальної праці й свідчило про турботливе ставлення вузу до продуктивності наукової праці викладача [5].

- мобільність вчених [1]: викладачів, докторантів та студентів. Без свободи вибору напряму досліджень, місця та оплати діяльності щодо проведення наукових досліджень неможливо говорити про повноцінну мотивацію наукової і науково-технічної діяльності (матимемо стимулювання, що не забезпечує ефективність діяльності й новизну наукових результатів).

Один із Зальцбурзьких принципів вимагає Збільшення мобільності: «... докторські програми мають шукати шляхи для того, щоб пропонувати географічну, так само як i міждисциплінарну, внутрішьносекційну мобільність та міжнародну співпрацю в межах інтегрованої кооперації між університетами та іншими партнерами».

Висновки. У зв'язку з відсутністю чіткого опису (відповідних програм, концепцій) підходів щодо організації наукових досліджень в інтересах освіти та університетів за кордоном представлений досвід та висновки, що викладено нижче доцільно розглядати як тенденції й перспективи розвитку системи організації наукового забезпечення системи вищої освіти та освітньої діяльності ВНЗ за кордоном і в Україні, що визначені авторами статті вперше.

1. Доцільно розрізняти два рівні організації (замовлення) наукових досліджень в інтересах вищої освіти:

- національний - замовником є державні інституції;

- університетський - замовником є вищі навчальні заклади.

2. Серед можливих виконавців наукових досліджень в інтересах вищої освіти слід розглядати таких:

- спеціалізовані підрозділи (установи), що знаходяться у підпорядкуванні органів управління освітою (з досвіду Франції);

- зовнішні організації, що проводять дослідження в інтересах вищої освіти (з досвіду США);

- групи (об'єднання) аналітиків, які залучаються до проведення дослідження в інтересах вищої освіти (з досвіду Великобританії);

- викладачі, які постійно здійснюють аналітичну діяльність щодо покращення комунікації зі здобувачами вищої освіти (загальноприйнята норма для усіх країн);

- науковці та здобувачі вищої освіти, які проводять дослідження у вищих навчальних закладах (загальноприйнята норма для усіх країн).

3. Основними завданнями проведення наукових досліджень в інтересах освіти доцільно визначити:

- забезпечення прийняття рішень у галузі освіти даними, що характеризують якість освіти у країні або окремій галузі. Наприклад, розроблення відповідних методів і статистичних показників оцінки якості військової освіти;

- виявлення проблемних питань удосконалення освіти та шляхів їх вирішення; 
- розроблення й ретельне тестування нових підходів до підвищення результатів навчання здобувачів вищої освіти;

- оцінювання програм і політики освіти (шляхів підготовки викладача, систем оцінки педагогічних та лідерських якостей викладача, ініціатив 3 удосконалення навчальних закладів, програм вибору навчального закладу);

- удосконалення механізмів ресурсного забезпечення (кадрового, інформаційного, матеріального, фінансового) галузі освіти.

4. Основними заходами щодо організації наукових досліджень в інтересах вищої освіти можуть (на вибір у кожному конкретному випадку) бути:

- фінансова (гранти, проекти, програми) підтримка наукових досліджень, проведення опитувань, програм довгострокової статистики, лабораторій передових технологій освіти;

- організація незалежного рецензування досліджень, спрямованих на підвищення якості освіти;

- оцінювання освітніх програм, програм розвитку й політики вищих навчальних закладів;

- фінансування програм вищої освіти, включно 3 докторськими програмами;

- забезпечення ресурсів для розширення використання даних i досліджень у процесі прийняття рішень у галузі освіти (підготовка фахівців для роботи з базами даних, забезпечення функціонування короткострокових курсів підвищення кваліфікації для працюючих статистиків і дослідників).

5. Основними заходами щодо організації наукових досліджень в інтересах університетів мають (обов'язкове проведення усіх заходів) бути:

- включення наукових досліджень у програми підготовки магістрів та докторів філософії;

- організація наукових досліджень для розвитку та покращення освітньої діяльності вищого навчального закладу;

- створення умов для обов'язкового використання результатів новітніх наукових досліджень під час навчального процесу;

- заходи щодо формування «мотиваційного ресурсу» наукових досліджень - комерціоналізація досліджень, фінансування підготовки докторантів за рахунок коштів отриманих на проведення досліджень, додаткова оплата викладачів, які проводять наукові дослідження, забезпечення мобільності викладачів, докторантів, студентів.

\section{ЛІТЕРАТУРА}

1. Дегтярьова I. О., Прокопенко Л. Л. Трансформації державного управління вищою освітою Польщі. http://poland.poland.su/soc_gov_no.html.

2. Кампюс Франс в Узбекистане. Електронний ресурс. Режим доступу: http://www.ouzbekistan.campusfrance.org/ru/page.

3. Кананикина Е. С. Система французского высшего образования. Режим доступу: http://e-notabene.ru/al/article_687.html

4. Луценко О. А. Основні ступені освітньої системи США. / Луценко О. А., Поливана Л. А. // Харківський Національний технічний університет сільського господарства імені 
Петра Василенка. Режим доступу: file://C:/Users/homebook/Downloads/90986-191493-1SM.pdf.

5. Півнева Л. Політика вищої освіти України й США в сфері університетських наукових досліджень: деякі аспекти. / Любов Півнева // Український науковий журнал «Освіта регіону». Режим доступу: http://social-science.com.ua/article/359.

6. Супян В. Б. США: Фундаментальная наука и государство /Российская академия наук. Институт США и Канады. Ежемесячный научный и общественно-политический журнал. - М.: Наука. - № 11(443) ноябрь 2006. - С. 10-18.

7. Тарасова О. В. Вища освіта в США: сучасний стан та пріоритети розвитку. / О.В. Тарасова // Вісник Національної академії Державної прикордонної служби України. file://C:/Users/homebook/Downloads/Vnadps_2011_3_9\%20(1).pdf.

8. Українсько-польські дні освіти, науки та інновацій в Києві. Форум. Режим доступу: http://upc.kpi.ua/?p=2911

9. Department for Education. Research at DfE [Електронний ресурс] - Режим доступу: https://www.gov.uk/government/organisations/department-for-education/about/research.

10. House of Tutors [Електронний pecypc]. - Режим доступу: http://www.houseoftutors.com.

11. Institute of Education Sciences. [Електронний ресурс] - Режим доступу: https://ies.ed.gov/.

12. Institute of Education Sciences. Biennial Report to Congress. 2013-2014 and 20152016 [Електронний ресурс] - Режим доступу: https://ies.ed.gov/pdf/IESBR2013_2016.pdf.

13. Instytut Badań Edukacyjnych. [Електронний ресурс] - Режим доступу: http://www.ibe.edu.pl/pl/o-instytucie/misja.

14. Institut Français de l' Éducation. [Електронний ресурс] - Режим доступу: http://ife.ens-lyon.fr/ife/institut/presentation.

15. Kirkland USA. Режим доступу: http://www.kirkland.edu.pl/ru/79-2013-04-23-13-4624/69-a.

16. National Center for Education Research. Research Programs. [Електронний ресурс] Режим доступу: https://ies.ed.gov/ncer/projects/.

\section{REFERENCES}

1. Dehtiarova, I.O., Prokopenko L.L. Transformatsii derzhavnoho upravlinnia vyshchoiu osvitoiu polshchi. [Transformation of the state of higher education in Poland]. http://poland.poland.su/soc_gov_no.html (in Ukrainian).

2. Kampyus Frans in Uzbekistan. [Elektronnyi resurs]. Rezhym dostupu: http://www.ouzbekistan.campusfrance.org/ru/page (in Russia).

3. Kananikina, E.S. Sistema francuzskogo vysshego obrazovaniya. [French higher education system.] Rezhym dostupu: http://e-notabene.ru/al/article_687.html (in Russia).

4. Lutsenko, O.A. Osnovni stupeni osvitnoi systemy SShA. [Basic education degree system of USA]./ Lutsenko O.A., Polyvana L.A. // Kharkivskyi Natsionalnyi tekhnichnyi universytet silskoho hospodarstva imeni Petra Vasylenka. Rezhym dostupu: file://C:/Users/homebook/Downloads/90986-191493-1-SM.pdf (in Ukrainian).

5. Pivneva, L. Polityka vyshchoi osvity Ukrainy y SShA v sferi universytetskykh naukovykh doslidzhen: deiaki aspekty. [Higher Education Policy Ukraine and the United States in the field of university research: some aspects]./ Liubov Pivneva // Ukrainskyi naukovyi zhurnal «Osvita rehionu». Rezhym dostupu: http://social-science.com.ua/article/35(in Ukrainian)

6. Tarasova, O.V. Vyshcha osvita v SShA: suchasnyi stan ta priorytety rozvytku. [Higher education in the United States: current status and development priorities]. / O.V. Tarasova // Visnyk Natsionalnoi akademii Derzhavnoi prykordonnoi sluzhby Ukrainy. Pedahohichni nauky 2011 3/2011 Rezhym dostupu: file://C:/Users/homebook/Downloads/Vnadps_2011_3_9\%20(1).pdf (in Ukrainian). 
7. Supian ,V.B. SShA: Fundamentalnaia nauka y hosudarstvo [Fundamentalnaya science and state] /Rossyiskaia akademyia nauk. Ynstytut SShA у Kanadы. Ezhemesiachnыi nauchnы у obshchestvenno-polytycheskyi zhurnal. - M.: Nauka. - № 11(443) noiabr 2006. - S. 10-18 (in Russia).

8. Ukrainian-Polish Days of Education, Science and Innovation in Kyiv. Forum. Rezhym dostupu: http://upc.kpi.ua/?p=2911

9. Department for Education. Research at DfE. [Elektronnyi resurs] - Rezhym dostupu: https://www.gov.uk/government/organisations/department-for-education/about/research.

10. House of Tutors. [Elektronnyi resurs]. - Rezhym dostupu: http://www.houseoftutors.com.

11. Institute of Education Sciences. [Elektronnyi resurs]. - Rezhym dostupu:https://ies.ed.gov/.

12. Institute of Education Sciences. Biennial Report to Congress. 2013-2014 and 20152016 [Elektronnyi resurs]. - Rezhym dostupu: https://ies.ed.gov/pdf/IESBR2013_2016.pdf.

13. Instytut Badań Edukacyjnych. [Elektronnyi resurs]. - Rezhym dostupu: http://www.ibe.edu.pl/pl/o-instytucie/misja.

14. Institut Français de l' Éducation. [Elektronnyi resurs]. - Rezhym dostupu: http://ife.enslyon.fr/ife/institut/presentation.

15. Kirkland USA. [Elektronnyi resurs]. - Rezhym dostupu: http://www.kirkland.edu.pl/ru/79-2013-04-23-13-46-24/69-a

16. National Center for Education Research. Research Programs. [Електронний ресурс] Режим доступу: https://ies.ed.gov/ncer/projects/.

\section{PЕЗЮМЕ}

Григорий Капослёз, кандидат психологических наук, старший научный сотрудник,

Юрий Бодрик, кандидат технических наук, старший научный сотрудник,

Елена Мельниченко

Национальный университет обороны Украины имени Ивана Черняховского

\section{Зарубежный опыт организации научных исследований в интересах высшего образования}

В статье представлен анализ опьта организации научных исследований в интересах высшего образования США, Великобритании, Франщии, Польши. В результате установлена неопределенность подходов в организаџии научных исследований в интересах высшего образования, но при этом обозначены уровни организации научных исследований, возможные исполнители этих исследований, основные задачи проведения этих исследований в интересах образования и мероприятия по организации научных исследований в области образования.

Ключевые слова: научные исследования; образование; отрасль; высшее учебное заведение. 


\section{SUMMARY}

Grigoriy Kaposlyoz,

Candidate of Psychological Science, senior researcher,

Iurii Bodryk,

Candidate of Technical Science, senior researcher,

Lina Melnichenko

National University of Defense of Ukraine named after Ivan Chernyakhovskyi

\section{Foreign experience of organization of scientific researches is in interests of higher education}

Introduction. Aspiration of Ukraine to be integrated in European space in the field of higher education stipulates the necessity of the detailed analysis of the developed countries on questions of organization of scientific researches in interests of higher education. A problem is in that today in normatively-legal documents the mechanisms of organization of the scientific providing are absent in industry of higher education.

Purpose: To educe key moments in organization of scientific researches in interests of higher education of the developed countries of the world.

Methods: The method of analysis and synthesis and the method of expert evaluations are used.

Results. Analysing experience of organization of scientific researches in industry of higher education it is set in the developed countries of the world, that the performers of scientific researches it is been:

special groups subordinated to customers;

external organizations;

groups of independent analysts;

teachers and students in higher educational institutions.

The basic tasks of realization of scientific researches are certain in interests of higher education, namely:

exposure of problem questions and ways of their decision;

development and testing of the new going studies;

evaluation of the programs and politics of education;

improvement of mechanisms of resource ensuring education.

Originality For the first time to been an analysis of the organization of scientific research in the system of higher education abroad.

Conclusion. The presented experience and conclusions it is expedient to examine as tendencies and prospects of development of the system of organization of the scientific providing in industry of higher education abroad and in Ukraine.

Key words: scientific research; education; branch; higher educational institution. 